\title{
Strigolactone-Induced Putative Secreted Protein 1 Is Required for the Establishment of Symbiosis by the Arbuscular Mycorrhizal Fungus Rhizophagus irregularis
}

\author{
Syusaku Tsuzuki, ${ }^{1,2}$ Yoshihiro Handa, ${ }^{1}$ Naoya Takeda, ${ }^{1,2}$ and Masayoshi Kawaguchi ${ }^{1,2}$ \\ ${ }^{1}$ Division of Symbiotic Systems, National Institute for Basic Biology, Nishigonaka 38, Myodaiji, Okazaki 444-8585, Aichi, Japan; \\ and ${ }^{2}$ Department of Basic Biology, School of Life Science, SOKENDAI (The Graduate University for Advanced Studies), \\ Nishigonaka 38, Myodaiji, Okazaki 444-8585, Aichi, Japan
}

Submitted 15 October 2015. Accepted 5 January 2016.

\begin{abstract}
Arbuscular mycorrhizal (AM) symbiosis is the most widespread association between plants and fungi. To provide novel insights into the molecular mechanisms of AM symbiosis, we screened and investigated genes of the AM fungus Rhizophagus irregularis that contribute to the infection of host plants. $R$. irregularis genes involved in the infection were explored by RNA-sequencing (RNA-seq) analysis. One of the identified genes was then characterized by a reverse genetic approach using host-induced gene silencing (HIGS), which causes RNA interference in the fungus via the host plant. The RNA-seq analysis revealed that 19 genes are up-regulated by both treatment with strigolactone (SL) (a plant symbiotic signal) and symbiosis. Eleven of the 19 genes were predicted to encode secreted proteins and, of these, SL-induced putative secreted protein 1 (SIS1) showed the largest induction under both conditions. In hairy roots of Medicago truncatula, SIS1 expression is knocked down by HIGS, resulting in significant suppression of colonization and formation of stunted arbuscules. These results suggest that SIS1 is a putative secreted protein that is induced in a wide spatiotemporal range including both the presymbiotic and symbiotic stages and that SIS1 positively regulates colonization of host plants by $R$. irregularis.
\end{abstract}

Arbuscular mycorrhizal (AM) fungi form symbiotic associations with a large number of land plant species (Brundrett 2009). Through these symbioses, AM fungi provide host plants with inorganic nutrients such as phosphorus and nitrogen compounds from the soil. In return, the AM fungi receive carbohydrates derived from photosynthetic products from the plants. AM fungi greatly promote the growth of host plants, especially in oligotrophic soils (van der Heijden et al. 2015). It is thought that AM symbiosis originated more than 400 million years ago and that it assisted ancestor plants to expand habitats onto the land (Redecker et al. 2000; Remy et al. 1994; Simon et al. 1993). Therefore, AM fungi have been essential for terrestrial ecosystems on earth from the Paleozoic Era to the present day.

Nucleotide sequence data of RNA-seq analysis in this study have been deposited in the DDBJ Sequence Read Archive under accession number DRA002591.

Corresponding author: M. Kawaguchi; E-mail: masayosi@nibb.ac.jp

*The $\boldsymbol{e}$-Xtra logo stands for "electronic extra" and indicates that nine supplementary figures and five supplementary tables are published online.

(c) 2016 The American Phytopathological Society
The mechanisms by which AM fungi establish symbiosis have been gradually elucidated over the past dozen years or so (Recorbet et al. 2013). In the nonsymbiotic stage, AM fungi randomly elongate hyphae to explore host roots, using lipids stored within their spores as their energy source (Bago et al. 2000). When the hyphae come close to plant roots, they perceive strigolactones (SLs) that are present in the rhizosphere. SLs are a kind of phytohormone that was identified as a signal factor for AM fungi (Akiyama et al. 2005). SLs enhance metabolic processes and hyphal branching and elongation in the AM fungi, and these processes facilitate direct contact between the AM fungi and host plants (Akiyama et al. 2005; Besserer et al. 2006, 2008).

AM fungi also secrete signaling molecules to the host plants, including lipochitooligosaccharides and chitin oligomers. These signals induce $\mathrm{Ca}^{2+}$ spiking, which is involved in the early AM symbiotic processes within plant cells (Genre et al. 2013; Maillet et al. 2011). These presymbiotic signal communications between AM fungi and host plants play important roles in the establishment of AM symbioses (Nadal and Paszkowski 2013).

After a hypha attaches to a host root, the AM fungus forms an appressorium on the root surface, then enters the root. This process is accompanied by the formation of a prepenetration apparatus, which is assumed to guide the hypha into the root (Genre et al. 2005). In the cortical tissue of the root, the intraradical mycelium (IRM) densely branches and forms a characteristic hyphal structure called the arbuscule, which is surrounded by a plant membrane named the periarbuscular membrane. Various transporters are used to exchange nutrients and other substances across this membrane between the arbuscule and the host plant. These transporters include the phosphate transporters MtPT4 and OsPT11 (Harrison et al. 2002; Kobae and Hata 2010), the half-ABC transporters STR/STR2 (Gutjahr et al. 2012; Zhang et al. 2010) in Medicago truncatula and Oryza sativa, the ammonium transporter GmAMT4.1 in Glycine max (Kobae et al. 2010), and the monosaccharide transporter MST2 in the AM fungus Rhizophagus irregularis (formerly Glomus intraradices) (Helber et al. 2011).

$R$. irregularis forms a symbiosis-specific extraradical mycelium (ERM) on the outside of the host root. This is composed of thick, linear runner hyphae and branched absorbing structures (BAS), which have diverged several times from the runner hyphae (Bago et al. 1998). R. irregularis eventually generates next generation spores at the tip of the BAS to complete its life cycle. AM fungi are obligate symbionts that do not produce next generation spores without symbiosis with host plants. Thus, the transitions from the nonsymbiotic to the presymbiotic and symbiotic stages are vital in the life cycles of AM fungi. These transitions are not well understood at the molecular level, 
because they are difficult to study in these obligate symbionts. One way to investigate AM fungal gene functions was demonstrated by Helber et al. (2011), who analyzed the functions of $M S T 2$ in $R$. irregularis using RNA interference (RNAi). They transformed host plants to express small interfering RNAs (siRNAs) that targeted MST2, in a process called host-induced gene silencing (HIGS).

The secreted proteins of AM fungi have been targeted for analysis because of their potential roles in interactions with host plants. Tisserant et al. (2013) identified genes encoding small secreted proteins that are highly up-regulated in the IRM, using RNA-sequencing (RNA-seq) analysis. Kloppholz et al. (2011) demonstrated that Secreted Protein 7 (SP7) in R. irregularis interacts with the ethylene-responsive factor MtERF19, which is involved in the immune system of $M$. truncatula. SP7 functions as an effector, and the interaction between SP7 and MtERF19 suppresses the host defense response. However, other secreted proteins of AM fungi have not yet been functionally characterized, and the secreted proteins that play key roles in symbiotic establishment remain virtually unknown.

To better understand the molecular mechanisms of AM symbiosis, we analyzed the transcriptome of $R$. irregularis by RNA-seq under different conditions. We identified genes that are up-regulated under SL-treated and symbiotic conditions. We then used the HIGS-mediated knockdown strategy to show that one putative secreted protein positively regulates the infection of host plants. On the basis of our results, we propose a novel mechanism for the establishment of AM symbiosis, in which SL contributes to AM fungal colonization via the putative secreted protein.

\section{RESULTS}

Identification of upregulated genes under both SL-treated and $\mathrm{AM}$ symbiotic conditions in $\boldsymbol{R}$. irregularis.

To identify genes of $R$. irregularis that are expressed in both the presymbiotic and symbiotic stages, we performed transcriptome analysis of the nonsymbiotic germinating spores (control), SL-treated germinating spores, and symbiotic ERM, using RNA-seq. The ERM were recovered from in vitro monoxenic cultures using carrot hairy roots as the host (Bécard and
Fortin 1988). Before the RNA-seq analysis, the effects of SL on $R$. irregularis were evaluated. It has been reported that SL treatment of the AM fungi Gigaspora spp. induces hyphal branching and elongation (Akiyama et al. 2005; Besserer et al. 2006). In R. irregularis, hyphal branching could not be evaluated, whereas promotion of hyphal elongation was confirmed by SL treatment (Supplementary Fig. S1). There was only a slight difference in hyphal elongation between hyphae treated with $0 \mu \mathrm{M}$ GR24 (an artificial SL) and those treated with $0.01 \mu \mathrm{M}$ GR24. The greatest effect on hyphal elongation was observed with $0.1 \mu \mathrm{M}$ GR24. Higher concentrations (1 and $10 \mu \mathrm{M}$ GR24) gradually decreased the effect, hyphal germination and elongation were completely inhibited at $100 \mu \mathrm{M}$ GR24. Thus, $0.1 \mu \mathrm{M}$ GR24 was used for SL treatments in later experiments.

In the transcriptome analysis, 34, 2,250, 3,201, and 656 differentially expressed genes (DEGs) were identified in the SL-treated germinating spores and the 4-, 6-, and 8-week cocultured ERM, respectively, when compared with the nonsymbiotic controls (Supplementary Table S1). In the 4-, 6-, and 8-week cocultured ERM, a set of genes involved in the nitrogen transfer pathway to host plants (GiNT, GiGS2, GiCPS, GiASS, and GiCAR) (Tian et al. 2010), ammonium transporter 1 (GintAMT1) (López-Pedrosa et al. 2006), monosaccharide transporter2 (MST2) (Helber et al. 2011), aquaporin 1 (GintAQP1) (Aroca et al. 2009), a STE12-like gene (GintSTE) (Tollot et al. 2009), and phosphate transporter (GiPT) (Harrison and van Buuren 1995; Maldonado-Mendoza et al. 2001) were significantly up-regulated (Supplementary Table S2). In contrast, these genes were not up-regulated by SL treatment. This result was consistent with previous studies showing that these genes are exclusively induced during AM symbiosis with host plants. The transcriptome analysis revealed that 19 genes were up-regulated in both SL-treated germinating spores and 4-week cocultured ERM (Table 1). Interestingly, 11 of the 19 genes were predicted by SignalP 4.1 to encode small proteins with secretory signal peptides at their N-terminal ends (Petersen et al. 2011) (Table 1; Supplementary Table S3).

We performed real-time quantitative reverse transcription polymerase chain reaction (qRT-PCR) analysis to verify that the 11 putative secreted protein genes shown in Table 1 are

Table 1. Rhizophagus irregularis genes upregulated under both strigolactone (SL)-treated and cocultured conditions in the RNA-seq analysis

\begin{tabular}{|c|c|c|c|c|c|c|}
\hline \multirow[b]{2}{*}{ Protein ID $^{\mathbf{a}}$} & \multirow[b]{2}{*}{ Annotation } & \multirow[b]{2}{*}{ Secretion signal $^{b}$} & \multirow[b]{2}{*}{ SL treatment $\mathbf{t}^{\mathrm{c}}$} & \multicolumn{3}{|c|}{ Cocultures $^{c}$} \\
\hline & & & & 4-Week & 6-Week & 8-Week \\
\hline 342269 & No hit & + & 2.55 (3.5E-05) & $7.40(7.3 \mathrm{E}-50)$ & 7.15 (2.5E-22) & $2.63(4.6 E-05)$ \\
\hline 347085 & No hit & + & 2.29 (1.1E-12) & $5.02(2.9 \mathrm{E}-38)$ & $4.30(4.6 \mathrm{E}-13)$ & $0.03(1.0 \mathrm{E}+00)$ \\
\hline 334310 & Hypothetical protein & + & $2.04(8.4 \mathrm{E}-10)$ & $4.16(4.2 \mathrm{E}-34)$ & 3.29 (1.5E-08) & $-0.52(7.0 \mathrm{E}-01)$ \\
\hline 348911 & LysM superfamily & + & $2.22(6.7 \mathrm{E}-12)$ & $4.16(2.1 \mathrm{E}-30)$ & 3.40 (3.4E-12) & $0.44(8.1 \mathrm{E}-01)$ \\
\hline 176092 & No hit & + & $2.42(5.9 \mathrm{E}-07)$ & $5.40(9.7 \mathrm{E}-30)$ & $4.79(1.5 \mathrm{E}-13)$ & $0.69(6.8 \mathrm{E}-01)$ \\
\hline 199622 & Histone $\mathrm{H} 3$ & & $2.02(7.0 \mathrm{E}-04)$ & 5.73 (1.2E-29) & 5.24 (9.8E-39) & 2.07 (1.8E-05) \\
\hline 339406 & No hit & + & 2.05 (1.9E-08) & 3.87 (1.4E-29) & 3.44 (6.9E-10) & $-0.56(6.1 \mathrm{E}-01)$ \\
\hline 31003 & No hit & + & $2.29(7.7 \mathrm{E}-04)$ & 3.99 (3.3E-28) & 3.46 (4.7E-17) & $-0.91(2.2 \mathrm{E}-01)$ \\
\hline 347485 & No hit & & $2.10(4.5 \mathrm{E}-06)$ & 5.02 (4.2E-27) & $3.42(6.8 \mathrm{E}-05)$ & $-1.98(4.1 \mathrm{E}-04)$ \\
\hline 348888 & Hypothetical protein & + & 2.36 (7.7E-07) & 3.42 (4.4E-27) & 2.46 (1.3E-09) & $-1.48(1.7 \mathrm{E}-02)$ \\
\hline 62093 & $\mathrm{~S} 1 / \mathrm{P} 1$ nuclease & & 1.73 (3.4E-05) & $3.36(3.6 \mathrm{E}-21)$ & 2.68 (6.9E-06) & $-0.92(1.2 \mathrm{E}-01)$ \\
\hline 26749 & No hit & + & $2.13(7.7 E-04)$ & $4.99(4.0 \mathrm{E}-20)$ & $4.87(4.2 \mathrm{E}-14)$ & $0.12(1.0 \mathrm{E}+00)$ \\
\hline 345761 & No hit & + & $2.14(2.8 \mathrm{E}-06)$ & $3.00(1.6 \mathrm{E}-19)$ & $1.98(8.4 \mathrm{E}-06)$ & $-1.39(2.2 \mathrm{E}-02)$ \\
\hline 336409 & HMG-box superfamily & & $4.44(1.0 \mathrm{E}-06)$ & $6.50(1.6 \mathrm{E}-17)$ & $6.05(3.2 \mathrm{E}-23)$ & $4.25(3.9 \mathrm{E}-13)$ \\
\hline 25979 & No hit & + & 1.83 (2.8E-06) & $2.76(8.4 \mathrm{E}-17)$ & $1.81(2.4 \mathrm{E}-05)$ & $-2.04(3.3 E-06)$ \\
\hline 341801 & No hit & & 2.21 (7.8E-09) & 2.38 (4.1E-10) & $0.68(2.4 \mathrm{E}-01)$ & -2.07 (1.8E-06) \\
\hline 91549 & Fatty acyltransferase-like subfamily & & $2.45(3.5 \mathrm{E}-05)$ & $3.48(1.5 \mathrm{E}-06)$ & $3.16(1.7 \mathrm{E}-04)$ & $-1.10(3.0 \mathrm{E}-01)$ \\
\hline 32380 & PIF1-like helicase & & 7.24 (3.3E-10) & $8.60(1.3 \mathrm{E}-05)$ & $7.98(2.5 \mathrm{E}-06)$ & $5.13(5.8 \mathrm{E}-03)$ \\
\hline 345846 & No hit & & $1.77(2.0 \mathrm{E}-05)$ & $1.38(5.5 \mathrm{E}-04)$ & $0.54(4.3 \mathrm{E}-01)$ & $-2.26(2.6 \mathrm{E}-09)$ \\
\hline
\end{tabular}


induced both by SL treatment and under symbiotic conditions. For this analysis, total RNAs were newly prepared from nonsymbiotic germinating spores (control), SL-treated germinating spores, and 6-week cocultured ERM. After SL treatment, seven of the 11 genes were significantly up-regulated compared with the controls (Fig. 1A). Among these seven genes, five were also significantly up-regulated in the ERM (Fig. 1B). We also analyzed the symbiotic ERM marker gene GiPT by qRT-PCR. GiPT was up-regulated in the 6-week cocultured ERM as reported previously (Maldonado-Mendoza et al. 2001) (Fig. 1B), and this demonstrated the validity of sampling from the ERM under symbiotic conditions. Therefore, we found that at least five genes are induced during both SL treatment and symbiosis. Among the proteins encoded by these five genes, it has already been reported that proteins with ID numbers 342269, 347085, 334310, and 176092 are also up-regulated in IRM (Tisserant et al. 2013).We also found that protein 348911 contains the LysM domain, while proteins 347085 and 348911 are cysteinerich.

Time-course analysis of spore germination rate and $S L$-induced putative secreted protein 1 expression.

Among the genes that encode the five putative secreted proteins, the fold change in expression, under both the SLtreated and symbiotic conditions, was greatest for the gene encoding protein 342269 , in both the RNA-seq and qRT-PCR analyses (Table 1; Fig. 1). No proteins homologous with 342269 have been identified in any other organism; thus, protein 342269 is a novel protein containing no characterized domains or structures apart from the signal peptide. We named the protein 'SL-induced putative secreted protein 1' (SIS1). Based on $R$. irregularis genome data from Tisserant et al. (2013), the SIS1 gene is an intronless 450-bp gene. We also found genes encoding two SIS1 homologous proteins in the $R$. irregularis genome. These are proteins 176092 and RirG205060 (Lin et al. 2014), which share 36.0 and $38.1 \%$ amino acid identity, respectively, with SIS1 (E-value $<1.0 \mathrm{E}-5$ in a BLAST search). These proteins have putative N-terminal signal peptides and conserved amino acid sequences (Supplementary Fig. S2). Protein 176092 was also shown to be upregulated under both the SL-treated and symbiotic conditions (Table 1; Fig. 1).

To investigate the timing of induction of SIS1 by SL, we performed time-course analyses of spore germination rates and SIS1 expression in $R$. irregularis grown on M medium without SL or with $0.1 \mu \mathrm{M}$ SL GR24. There was little difference in germination rates between the SL-treated and control spores (Fig. 2A). The germination rates were around $30 \%$ at 3 days after inoculation (dai) and reached more than $80 \%$ at 5 dai for both the treated and control spores (Fig. 2A). At 5 dai, some hyphal development was already observed (Supplementary Fig. S3). SIS1 expression could not be detected in either the control or the SL-treated germinating spores at 1 and 3 dai (Fig. 2B). SIS1 expression was detected at 5 dai, and the expression level was significantly higher in the SL-treated germinating spores than the controls at this time (Fig. 2B). At 7 dai, SIS1 expression was much more highly induced in the SL-treated samples (Fig. 2B). These results suggest that SIS1 expression occurs during hyphal elongation and that the dramatic increase in SISI induction by SL is associated with hyphal elongation.

\section{Knockdown of SIS1 by HIGS.}

To analyze the functions of SIS1 during AM symbiosis, we used HIGS to knock down expression of SIS1, because a method for the direct transformation of AM fungi has not yet been developed. HIGS involves the transformation of the host plant with a silencing construct targeted to a fungal gene and was used to knockdown expression of a $R$. irregularis MST2 gene by Helber et al. (2011). We designed our HIGS construct to expresses a hairpin RNA that targeted a 330-bp partial sequence of SIS1 (Supplementary Fig. S4) and caused RNAi within $R$. irregularis-infected host roots.

To determine whether the 330-bp double-stranded RNA (dsRNA) derived from the SIS1-HIGS construct appropriately induces RNAi of SIS1, we used NEXT-RNAi software (Horn et al. 2010) to evaluate the efficiency and predict the targets of
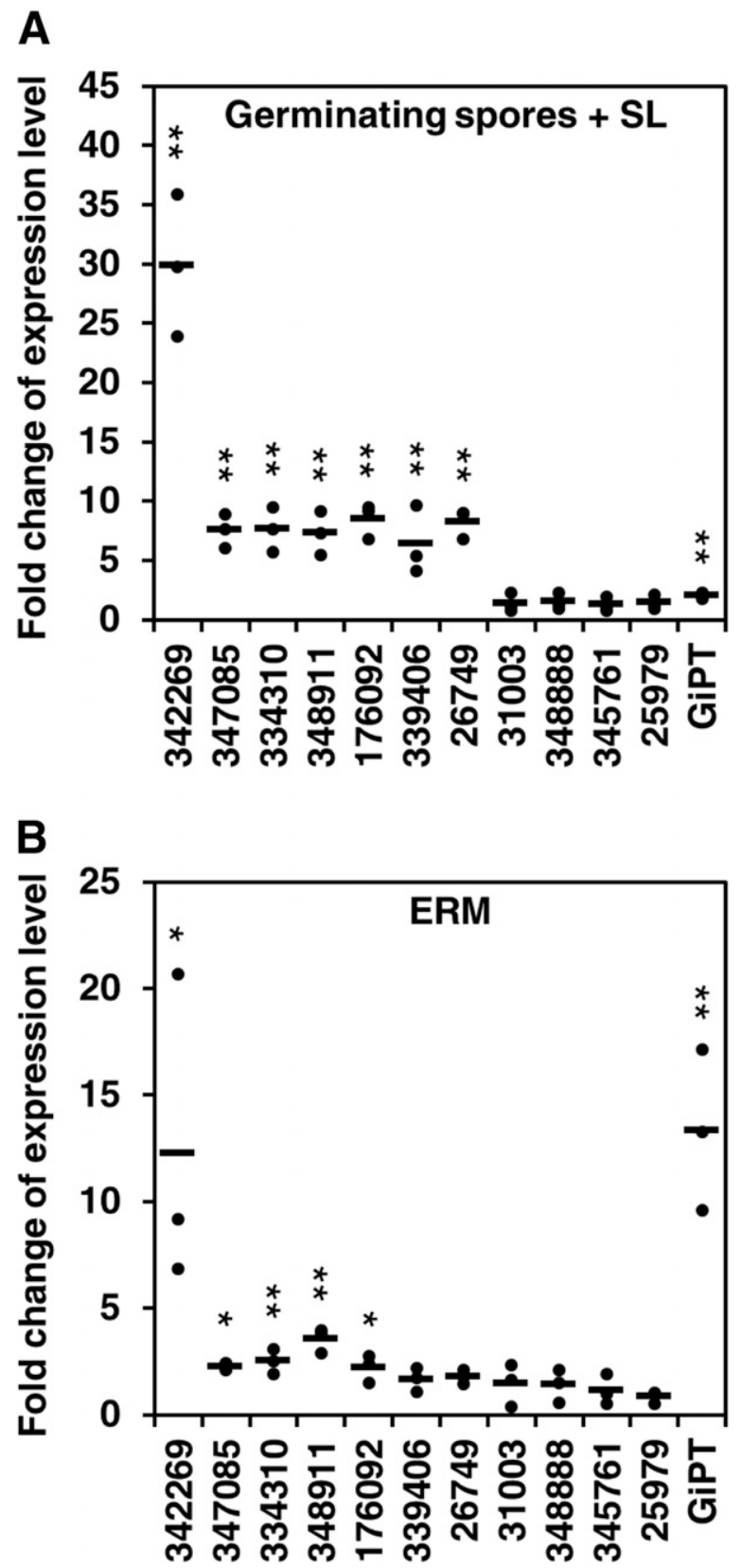

Fig. 1. Expression analysis of the 11 putative secreted protein genes and GiPT in A, strigolactone (SL)-treated germinating spores and $\mathbf{B}$, 6week-cocultured extraradical mycelium (ERM) by quantitative reverse transcription-polymerase chain reaction. The expression levels were normalized against translation elongation factor $1 \alpha$ of Rhizophagus irregularis $(R i T E F)$ and were represented by fold changes compared with expression in the nonsymbiotic germinating spores (control). The numbers on the horizontal axes represent protein identification numbers derived from the Joint Genome Institute. The circles represent data points $(n=3)$. The horizontal bars represent means of the three biological repeats. Asterisks indicate statistically significant differences to the control in the Student's $t$ test. $(*, P<0.05$ and $* *, P<0.01)$ 
the dsRNA. When the 330-bp dsRNA is cleaved into 21nucleotide siRNAs, 310 siRNA patterns can be generated. Of these, 100 were predicted to be efficient, using NEXT-RNAi (Supplementary Table S4). CA[ACGT] tandem trinucleotide repeats can have nonspecific and cytotoxic effects (Ma et al. 2006); however, these were not detected in the 330-bp sequence. Therefore, it is likely that the 330-bp dsRNA has enough efficiency to cause RNAi of SIS1. Target prediction of the 330-bp dsRNA against the $R$. irregularis coding sequence (CDS) database indicated that only SIS1 is the on-target gene and that there are no off-target genes. In addition, target prediction against the $M$. truncatula CDS database showed that there are no target genes in that species. This in silico analysis indicated that no off-target genes exist in the predicted genomes of either $R$. irregularis or M. truncatula.

We used hairy roots transformed with the empty vector (EV) and without the vector (no vector [NV]) as controls. Three independent hairy root lines transformed with the SIS1HIGS construct and an EV line showed expression of the
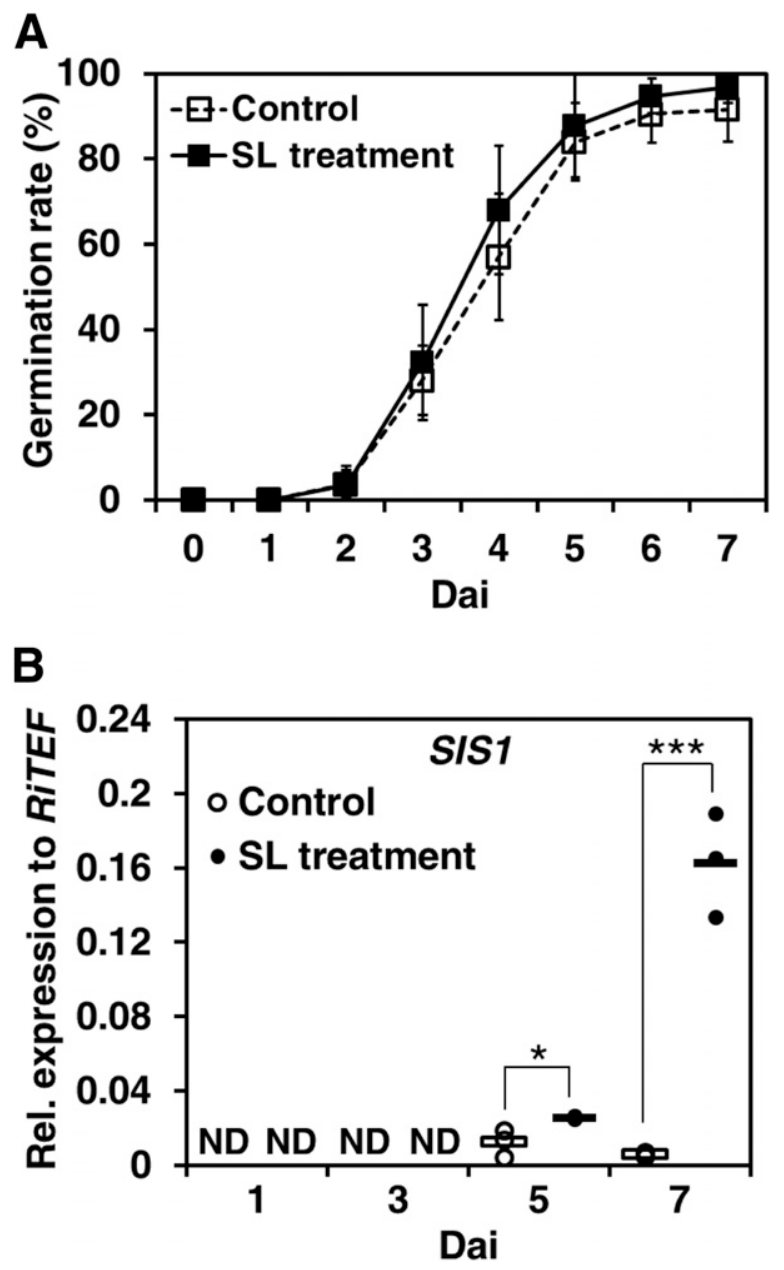

Fig. 2. Time-course analyses of spore germination rates and SIS1 expression. A, Germination rates of Rhizophagus irregularis spores under strigolactone (SL)- and nontreated (control) conditions were calculated each day for 1 week $(n=8)$. Error bars represent the standard deviation. B, SIS1 expression levels under SL- and nontreated (control) conditions were determined at 1, 3,5, and 7 days after inoculation (dai) by quantitative reverse transcription-polymerase chain reaction analysis. These expression levels were normalized to RiTEF. The white and black circles represent data points for control and SL treatments $(n=3)$. The horizontal bars represent means of the three biological repeats. Asterisks indicate statistically significant differences in the Student's $t$ test. ( $*, P<0.05$ and $* * *, P<0.001)$. ND, not detected. cotransformation marker eGFP (enhanced green fluorescent protein) (Supplementary Fig. S5). Furthermore, expression of the SIS1-HIGS construct was detected in the three lines transformed with the SIS1-HIGS construct by RT-PCR but not in the EV line (Supplementary Fig. S6). These results confirmed that the 330-bp SIS1 fragment was expressed in the transgenic M. truncatula lines.

Samples of the SIS1-HIGS, NV, and EV hairy roots were each infected with approximately $50 \mathrm{R}$. irregularis spores in in vitro monoxenic cultures and were then analyzed for AM developmental phenotypes at 8 weeks after inoculation (wai). Parameters of colonization (i.e., frequency of mycorrhiza in the root system, intensity of mycorrhizal colonization in the root system, and arbuscule abundance in the root system) (Trouvelot et al. 1986) were significantly lower in the SIS1-HIGS roots than in the NV and EV controls (Fig. 3A, B, and C). In accordance with those results, the spore formation numbers in the monoxenic culture with SIS1-HIGS roots were significantly lower than those in the controls (Fig. 3D). To confirm that SISI expression was suppressed by HIGS, SIS1 expression was evaluated in the IRM of SIS1-HIGS roots and EV controls at 4 wai by qRT-PCR. For this analysis, the primer set amplified a part of the SIS1 sequence outside the 330-bp fragment targeted by the SIS1-HIGS construct. As shown in Figure 3E, SIS1 expression levels in the IRM tissues of the SIS1-HIGS roots were significantly lower than those in the EV controls. We also performed qRT-PCR analyses of Protein ID 176092 and RirG205060, which are homologs of SIS1, in the IRM of SIS1HIGS L1 and EV roots. No significant differences were detected in the expression levels of the two genes $(P=0.82$ and $P=0.60$ in the Student's $t$ test) (Supplementary Fig. S7A and B). Therefore, the presence of the SIS1-HIGS RNAi construct suppressed expression of SIS1, and this suppression was associated with reduced colonization by $R$. irregularis within the SIS1-HIGS host roots. These results imply that SIS1 is required for infection of host roots by $R$. irregularis. The expression levels of translation elongation factor $1 \alpha($ RiTEF) in the IRM of SIS1-HIGS L1 and EV roots were also evaluated by normalization against Actin (RiAct, Protein ID 339571), which is a commonly used normalization gene in qRT-PCR analyses of other organisms. The results demonstrated the consistency of RiTEF expression in the IRM of SIS1-HIGS L1 and EV roots. This suggests that RiTEF is a reliable normalization gene for this study.

We also used qRT-PCR to examine the expression of AM marker genes in $M$. truncatula SIS1-HIGS hairy roots in the monoxenic culture with $R$. irregularis at 4 wai. The expression levels of MtPT4 and the subtilisin-like Ser protease (subtilase) gene SbtM1 homolog of M. truncatula (MtSbtM1, XM_003611148) were significantly lower in the SIS1-HIGS hairy roots than in the EV controls (Fig. 4A and B). This result indicated that $\mathrm{AM}$ symbiotic responses in the host plant were repressed in the SIS1-HIGS hairy roots, and this was consistent with the suppression of colonization parameters in the SIS1HIGS hairy roots (Fig. 3A, B, and C).

To further characterize the effects of SIS1-HIGS on AM fungal colonization, we observed, in detail, the hyphal structures of $R$. irregularis within the SIS1-HIGS hairy roots at 8 wai. The IRM densities and abundance of arbuscules were lower in the SIS1-HIGS hairy roots than in the EV controls, even in the region that was infected by $R$. irregularis (Fig. 3B and C; Supplementary Fig. S8). Moreover, the arbuscules in EV control hairy roots were mature and finely branched, whereas the majority of arbuscules in the L1, L2, and L3 SIS1-HIGS hairy roots displayed defective morphology (Fig. 4C and D; Supplementary Fig. S9). These observations corresponded with the decline in expression of MtPT4, which is specifically expressed in periarbuscular membranes (Pumplin and Harrison 
2009) (Fig. 4A, C, and D). The stunted arbuscules are an indication of incomplete AM symbiosis. These results suggest that SIS1 contributes to the establishment of AM symbiosis in R. irregularis.

\section{DISCUSSION}

AM fungi can colonize a wide range of plants, whereas other mycorrhizal and pathogenic fungi infect only limited numbers of host plants. Although the proteins secreted by AM fungi are suspected to play important roles in interactions with host plants (Kloppholz et al. 2011; Lin et al. 2014; Tisserant et al. 2013), their functions in AM development are poorly understood. We performed RNA-seq and qRT-PCR analyses of $R$. irregularis and identified five genes that are up-regulated in both SL-treated germinating spores and symbiotic ERM and that encode putative secreted proteins (SIS1, 347085, 334310, 348911, and 176092) (Table 1; Fig. 1). Among these proteins, we found that 348911 has the LysM domain, whereas 347085 and 348911 are cysteine-rich proteins. These features are consistent with those of some plant pathogen-encoded effectors that suppress defense responses in host plants (Stergiopoulos and de Wit 2009). This suggests that proteins 347085 and 348911 may have functions in plant-microbe interactions. Furthermore, a previous RNA-seq analysis showed that the genes encoding SIS1, 347085, 3343410, and 176092 are upregulated in the IRM compared with nonsymbiotic $R$. irregularis tissues (Tisserant et al. 2013). In summary, we and others have found that the genes encoding these putative secreted proteins are induced in a wide spatiotemporal range across the presymbiotic to the symbiotic states of $R$. irregularis.

SIS1 expression could not be detected in germinating $R$. irregularis spores at 1 and 3 dai but was detected on and after 5 dai, when more than $80 \%$ of the spores had germinated and some hyphae had begun elongating (Fig. 2). This suggests that SIS1 is expressed at the hyphal elongation stage after germination. SISI expression levels were somewhat increased by SL treatment at 5 dai and greatly increased at 7 dai, when the hyphae had further elongated (Fig. 2). Native SLs are known to be very susceptible to degradation (Akiyama et al. 2005), and for this reason, SLs are mainly found in the rhizospheres of host plants (Nadal and Paszkowski 2013). Therefore, we infer that in R. irregularis, SIS1 is expressed at low levels before the fungus recognizes the roots of a host plant; however, after the fungal hyphae detect SLs in the rhizosphere, SIS1 expression is drastically increased. This pattern of SIS1 expression supports our contention that SIS1 is involved in the infection of host plants. Moreover, SIS1 would be a useful and novel marker gene for SL induction and expression in the ERM of symbiotic $R$. irregularis because little is known about AM fungal genes that are induced by SL.

In a previous study, the monosaccharide transporter gene MST2 of $R$. irregularis was knocked down using HIGS, and the results suggested that $M S T 2$ is essential for AM symbiosis (Helber et al. 2011). We adopted the HIGS strategy to analyze the function of SIS1 in AM development and found that colonization levels were significantly suppressed in hairy roots after
A

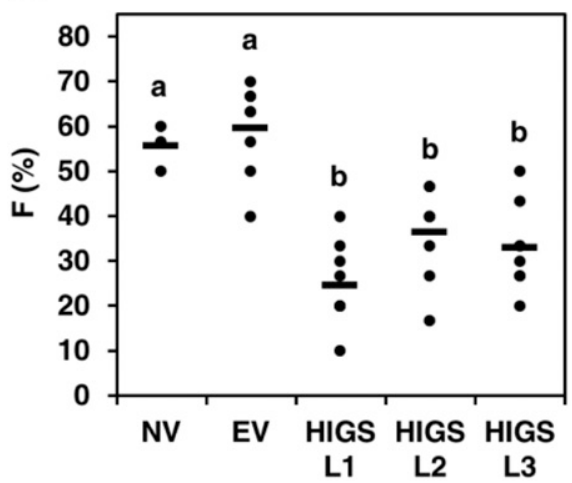

B

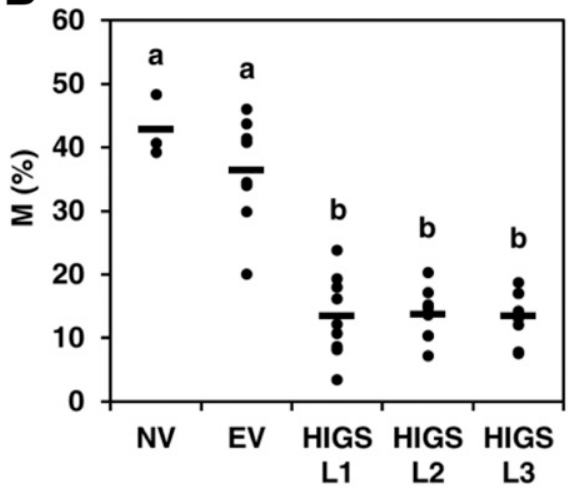

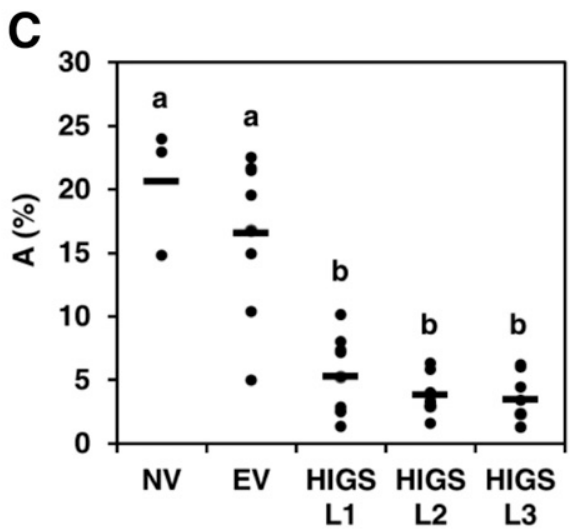
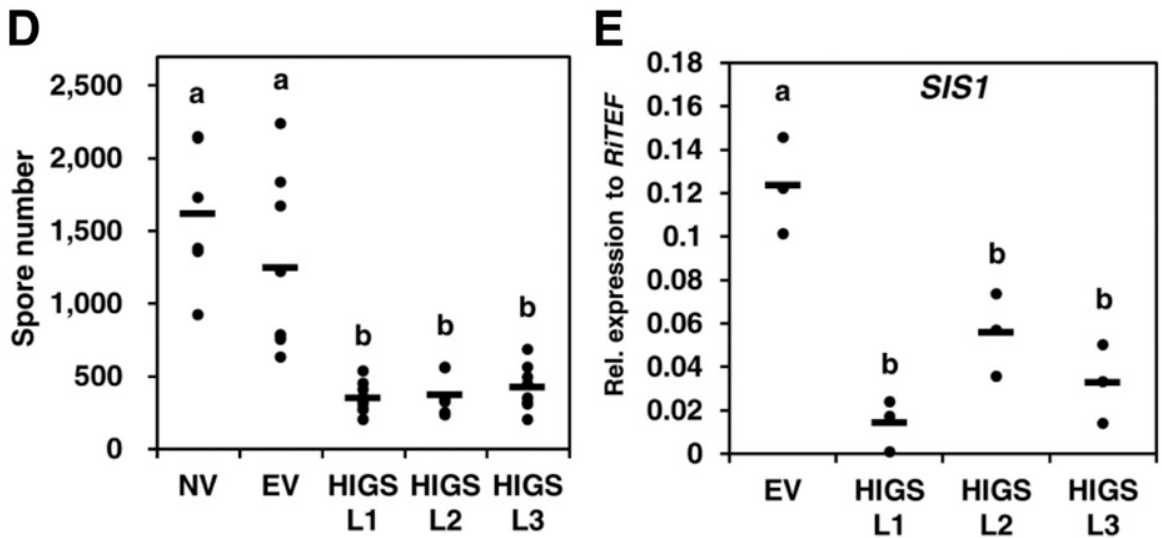

Fig. 3. Colonization, spore formation number, and SIS1 expression in the in vitro monoxenic culture with SIS1-host-induced gene silencing (HIGS) hairy roots. $\mathbf{A}, \mathbf{B}$, and $\mathbf{C}$, Colonization levels were analyzed at 8 weeks after inoculation (wai) of the spores in the monoxenic culture (F\%, frequency of mycorrhiza in the root system; M\%, intensity of mycorrhizal colonization in the root system; A\%, arbuscule abundance in the root system). $n=3$ (no vector [NV]), 8 (empty vector [EV]), 9 (HIGS L1), 8 (HIGS L2), and 8 (HIGS L3). D, Spore numbers newly formed in the culture plate at 8 wai. $n=6$ (NV), 8 (EV), 10 (HIGS L1), 8 (HIGS L2), 8 (HIGS L3). E, SIS1 expression levels of intraradical mycelium were determined at 4 wai. These were normalized to RiTEF. $n=3$. The circles represent data points and the horizontal bars represent means of the biological repeats. Different letters indicate significant differences in the Tukey honestly significant difference test $(P<0.05)$. 
knockdown of SIS1 (Fig. 3). This result suggests that SIS1 positively regulates the infection of host plants by $R$. irregularis. However, our observation of these phenotypes has been restricted to unconventional conditions using hairy roots. A SIS1-HIGS experiment using stable plant transformants will, therefore, be worth conducting in order to examine SIS1 functions under more normal conditions.

Most of the arbuscules in the SIS1-HIGS hairy roots displayed stunted morphologies (Fig. 4D), and this was also observed in the $R$. irregularis arbuscles after HIGS-mediated knockdown of MST2 (Helber et al. 2011). Furthermore, the partial or complete loss-of-function of some host genes involved in AM symbiotic development results in similarly stunted arbuscules, even though the functions or functional sites of these genes and the associated phenotypes are unrelated to one another. Such genes include Vapyrin, MSBP1, and VAMP72s (Feddermann et al. 2010; Ivanov et al. 2012; Kuhn et al. 2010; Pumplin et al. 2010), the transcription factor gene RAM2 (Wang et al. 2012), and genes encoding the transporters $S T R / S T R 2$ and MtPT4 (Javot et al. 2007; Zhang et al. 2010). Therefore, it appears that SIS1 along with these other plant and fungal genes is essential for AM symbiosis. Additional SIS1-HIGS experiments to study the time course of arbuscule formation will be helpful in determining whether SIS1 is involved in either arbuscule formation, arbuscule stability, or both.

It has been shown that SL enhances AM hyphal branching and elongation and activates certain metabolic pathways
(Akiyama et al. 2005; Besserer et al. 2006, 2008). Moreover, SL increases the amount of chitin oligomers in AM fungal exudates and these induce $\mathrm{Ca}^{2+}$ spiking, which is involved in AM symbiotic signaling in plant cells (Genre et al. 2013). In addition to these findings, we identified a novel mechanism of SL action that contributes to AM fungal infection via the induction of SIS1. This novel mechanism further strengthens the commonly accepted theory that SL is the AM symbiotic signal. It has been reported that AM colonization levels are reduced in host plants with mutations in the SL biosynthetic genes carotenoid cleavage dioxygenase 7 (CCD7) and CCD8 (GomezRoldan et al. 2008; Koltai et al. 2010; Vogel et al. 2010). These phenotypes may result from the reduced levels of SISI expression when $R$. irregularis infects these mutant host pants.

SIS1 does not contain any previously characterized conserved domains, apart from the secretory signal peptide. Accordingly, we assume various possible functions of SIS1 in AM fungal infection. In plants, microbe-associated molecular patterns (MAMPs) derived from plant pathogens are known to be required for recognition of the pathogens. Among the MAMPs, some proteins of plant-pathogenic bacteria have been reported to induce plant defense responses such as the hypersensitive response (Albert 2013). Flagellin and elongation factor $\mathrm{Tu}$ (EF-Tu) are well-studied proteinaceous MAMPs, and the plant receptors flagellin sensing 2 (FLS2) (Gómez-Gómez and Boller 2000) and EF-Tu receptor (EFR) (Zipfel et al. 2006) have also been identified. Specific peptide regions of about 20 amino

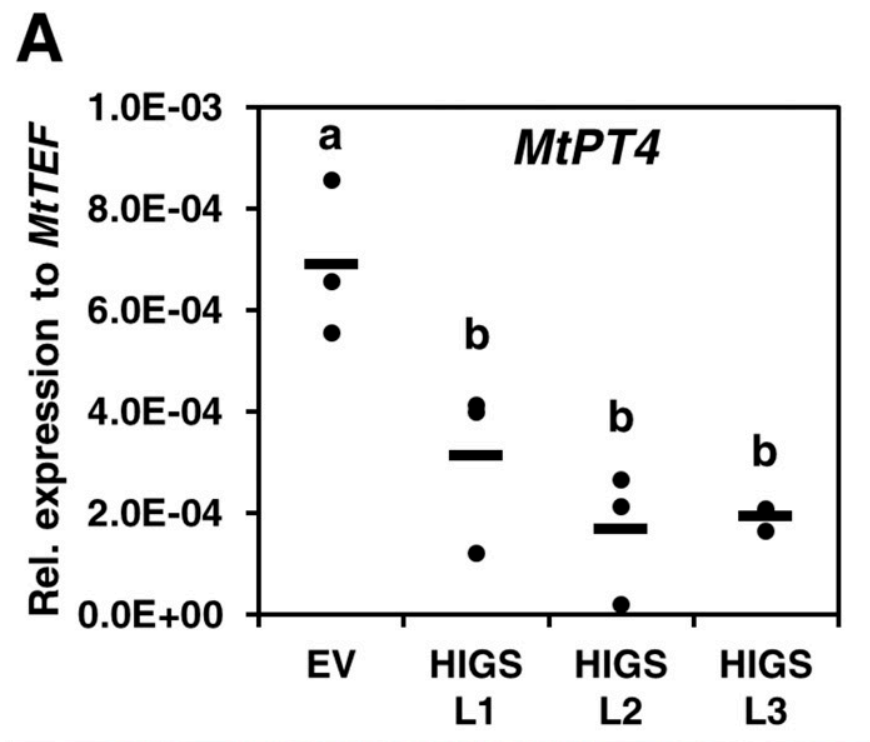

B
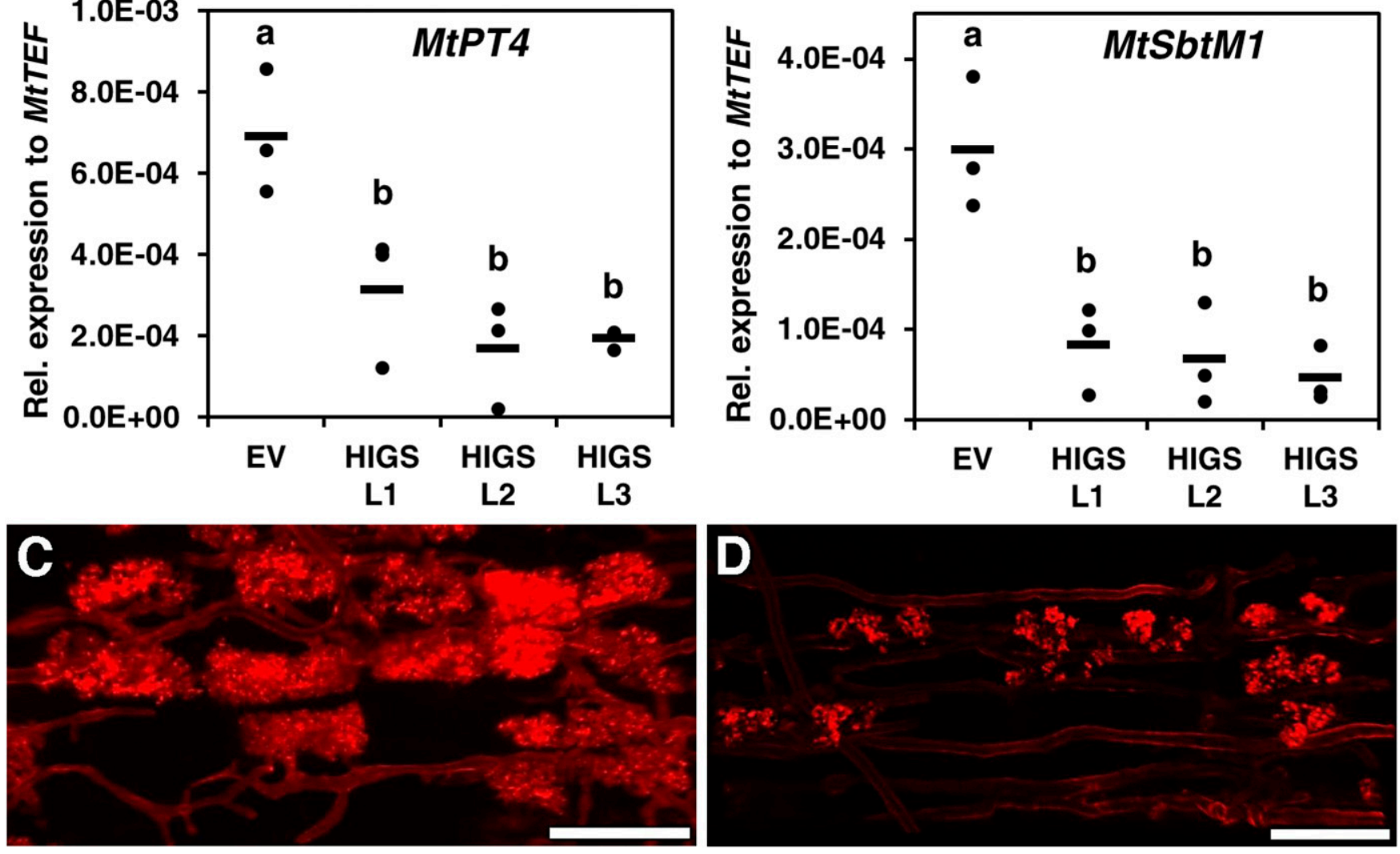

Fig. 4. Expression of host arbuscular mycorrhizal marker genes and morphology of arbuscules in SIS1-host-induced gene silencing (HIGS) roots. A and B, Phosphate transporter4 (MtPT4) and subtilase gene MtSbtM1 of Medicago truncatula expression levels in emptry vector (EV) and SIS1-HIGS hairy roots at 4 weeks after inoculation (wai). These were normalized against translation elongation factor $1 \alpha$ of $M$. truncatula (MtTEF). The circles represent data points $(n=3)$. The horizontal bars represent means of the three biological repeats. Different letters indicate significant differences in the Tukey honestly significant difference test $(P<0.05)$. C and $\mathbf{D}$, Arbuscules labeled with wheat germ agglutinin (WGA)-Alexa Fluor 594 dye at 8 wai in EV (C) and SIS1-HIGS L1 (D) hairy roots. Bars represent $50 \mu \mathrm{m}$. 
acids are conserved among the proteinaceous MAMPs of various plant pathogenic bacteria, and play central roles in recognition by their respective plant receptors (Felix et al. 1999; Kunze et al. 2004). It seems possible that certain amino acid residues of SIS1 similarly contribute to the host plants' recognition of AM fungi and that this recognition might induce symbiotic responses in the host plants. In previous studies, lipochitooligosaccharides and chitin oligomers have received attention as signal factors derived from AM fungi (Genre et al. 2013; Maillet et al. 2011), and in addition, our study suggests that proteinaceous signal factors might exist in AM fungi. Furthermore, the effector protein SP7 was identified in $R$. irregularis and was demonstrated to interact with MtERF19, which is involved in the immune program of $M$. truncatula (Kloppholz et al. 2011). It can be hypothesized that SIS1 may also have an effector-like activity that suppresses defense responses in host plants. Moreover, SIS1 may also play roles in the regulation AM symbiotic development by acting within $R$. irregularis cells.

It can be concluded that SIS1 is a novel putative secreted protein that is induced by both SL treatment and AM symbiosis in $R$. irregularis, and that it positively regulates AM colonization. It is not yet clear how and where SIS1 functions, however; further characterizations of SIS1 functions are likely to lead to a better understanding of the mechanisms controlling the establishment of AM symbiosis.

\section{MATERIALS AND METHODS}

\section{Biological materials and growth conditions.}

Seedlings of $M$. truncatula Jemalong A17 were prepared as described by Takeda et al. (2015) with slight modifications. $M$. truncatula seeds were rubbed with sandpaper and were sterilized in $70 \%$ ethanol $(1 \mathrm{~min})$ followed by bleaching $(0.1 \%$ sodium hypochlorite, $0.1 \%$ Tween 20 ) for $15 \mathrm{~min}$. The seeds were allowed to absorb water overnight, then, were placed on $1.0 \%$ agar plates to germinate $\left(2\right.$ days, $24^{\circ} \mathrm{C}$, dark). The seedlings were grown for another 2 days $\left(24^{\circ} \mathrm{C}, 16 \mathrm{~h}\right.$ light and $8 \mathrm{~h}$ dark). These seedlings and carrot (Daucus carota) were transformed with Agrobacterium rhizogenes AR1193 into hairy roots according to Takeda et al. (2013) and Danesh et al. (2006). The generated hairy roots were separated from the plants and were cultured on M medium (Bécard and Fortin 1988). The cultured roots were used for in vitro monoxenic culture of R. irregularis DAOM 197198 (Premier Tech) as described by Bécard and Fortin (1988) with some alterations. A 2- to 3-cm fragment of the hairy roots was cultured on M medium solidified with $0.4 \%$ gellan gum for 2 weeks, and then, approximately $50 R$. irregularis spores were placed near the hairy roots. Before inoculation, the spores were isolated from $R$. irregularis hyphae by density gradient centrifugation with $48,32,16$, and $8 \%$ (vol/vol) gastrografin (Bayer Yakuhin), using a method adapted from Furlan et al. (1980). All plates were incubated in the dark at $28^{\circ} \mathrm{C}$ for 4,6 , or 8 weeks.

Axenic SL-treated or nonsymbiotic (control) R. irregularis cultures were prepared using approximately 10,000 spores on $\mathrm{M}$ medium with or without $0.1 \mu \mathrm{M}$ artificial SL GR24 and were grown in the dark at $28^{\circ} \mathrm{C}$ for 1 week. Axenic cultures were also treated with $0.01,1,10$, and $100 \mu \mathrm{M}$ GR24 or for 1,3 , and 5 days in order to analyze hyphal elongation and the time course of SIS1 expression.

\section{Isolation of the fungus and RNA extraction.}

Spores and hyphae were collected from the in vitro monoxenic and the axenic cultures. The host roots in the monoxenic cultures were carefully removed with tweezers under a stereomicroscope SZX7 (Olympus). The solidified M medium was dissolved using citrate buffer $(1.7 \mathrm{mM}$ citric acid, $8.3 \mathrm{mM}$ sodium citrate, $\mathrm{pH}$ 6.0) as described by Doner and Bécard (1991). Briefly, citrate buffer was added to the gellan gum medium at three to four times the volume, and the mixture was shaken at $37^{\circ} \mathrm{C}$ for $5 \mathrm{~min}$ to dissolve the medium. The fungus was precipitated by centrifugation, was rinsed once with distilled water, was recentrifuged, and was frozen with liquid nitrogen after removal of the water. IRM tissue from the monoxenic culture was harvested with the host roots and was then frozen. Total RNAs were extracted from the frozen tissues using PureLink Plant RNA Reagent (Life Technologies), following the manufacturer's instructions.

\section{Transcriptome analysis by RNA-seq.}

RNA-seq analysis was performed as described by Takeda et al. (2015) and Handa et al. (2015). The total RNAs were purified using the RNeasy mini kit (Qiagen) and the RNase-free DNase set (Qiagen). For each sample, we used an RNA electrophoresis profile to calculate the RNA integrity number (RIN), which is an indicator of the degree of undegraded RNA (Schroeder et al. 2006). These analyses were performed using the RNA 6000 nano kit (Agilent Technologies) and the 2100 Bioanalyzer system (Agilent Technologies). The quality criterion for the RIN number was that it should be equal to or greater than 7.40, and all samples used in the experiment met this criterion. RNA-Seq libraries were constructed from 170 to $500 \mu \mathrm{g}$ of total RNAs isolated from nonsymbiotic (control), SL-treated, 4-week cocultured, 6-week cocultured, and 8-week cocultured fungi, with three biological replicates, using the TruSeq RNA sample preparation kit (Illumina) according to the manufacturer's instructions. The quality of each library was checked using the 2100 Bioanalyzer and was quantified using a KAPA library quant kit (Kapa Biosystems). Paired-end sequencing (101 bp each) was carried out using the Illumina HiSeq 2000 instrument (Illumina). The averaged read numbers for the three replicates of the nonsymbiotic control, SL-treated, and 4-, 6-, and 8-week cocultured samples were 9.5, 9.9, 5.3, 3.7, and 5.9 mega reads, respectively. Datasets of the short reads were registered in the DDBJ Sequence Read Archive (accession number: DRA002591). The mapping of these reads against the $R$. irregularis genome assembly (Gloin1; Joint Genome Institute), provided by Tisserant et al. (2013), was performed as described by Handa et al. (2015). The count number of the reads mapped on each transcript was normalized as the reads per kilobase of exon per million mapped reads, as described by Mortazavi et al. (2008) and Nagalakshmi et al. (2008). To determine DEGs when compared with the nonsymbiotic controls, the raw gene expression counts were calculated based on iDEGES/edgeR in the TCC package (Robinson et al. 2010; Sun et al. 2013). DEGs were evaluated by using a false discovery rate of less than 0.001 as the statistical criterion.

\section{Expression analysis by real-time qRT-PCR.}

Genomic DNA in the total RNA solutions was degraded using DNase I (Takara Bio) and removed by treatment with an acid phenol and chloroform (1:1) solution. Real-time qRT-PCR analysis was performed using the cleaned up total RNA as the template, the ReverTra Ace qPCR RT kit (Toyobo) and the Thunderbird qPCR Mix (Toyobo) with the LightCycler 96 (Roche), following the manufacturer's instructions. Non-RT control experiments were used to confirm that there was no genomic DNA contamination. The primer sets are listed in Supplementary Table S5. Expression levels were normalized against the housekeeping gene TEF in $R$. irregularis or M. truncatula, as reported previously (Helber et al. 2011; Kloppholz et al. 2011), then fold change values were obtained 
by comparison with the nonsymbiotic controls. Mean values were calculated for three biological replicates. Melting curve analysis of each amplicon showed single peaks.

\section{HIGS.}

A part of the SIS1 coding sequence (330 bp) was amplified from cDNA, using Prime STAR GXL (Takara) and the SIS1HIGS construct primer set, and was cloned into pENTR D/TOPO (pENTR D/TOPO cloning kit; Life Technologies). The entry clone was converted into the binary vector pK7GWIWG2 (I) (Karimi et al. 2002) that has been inserted with $e G F P$ as the cotransformation marker gene (rolDpro:eGFP:35Sterm) (Takeda et al. 2009) using Gateway LR Clonase enzyme mix (Invitrogen), resulting in the SIS1-HIGS construct expressing SIS1 hairpin RNA. We confirmed that the 330-bp fragments of SIS1 were inserted into two cloning sites of pK7GWIWG2(I) by sequencing with the pK7GWIWG2(I) primer set. Sequencing was performed with a 3130xl Genetic Analyzer (Applied Biosystems).

The SIS1-HIGS construct and the EV were transferred to Agrobacterium rhizogenes AR1193, which was used to transform M. truncatula hairy roots. Three independent SIS1-HIGS hairy root lines and one EV hairy root line were generated for the in vitro monoxenic cultures described above. To detect transcripts of the 330-bp SISI fragments in the transgenic hairy roots, total RNAs were isolated from the nonmycorrhizal EV and SIS1-HIGS hairy roots and were purified as described above. Subsequently, RT-PCR analysis was performed using the SIS1-HIGS construct primer set. Control experiments without the RT reaction (non-RT control) were also performed.

Eight weeks after inoculation of the spores in the monoxenic cultures, the IRM inside the hairy roots was visualized by ink staining, as described by Takeda et al. (2015). Colonization was quantified using the ink-stained IRM and the upright microscope BX50 (Olympus) according to the method of Trouvelot et al. (1986), and newly formed spores on the outsides of the host roots were also counted under the stereoscope SZX7 at 8 wai. These numbers were used for analysis of the SIS1-HIGS phenotype. Any HIGS phenotype is expected to emerge after $R$. irregularis colonizes within the host roots. Therefore, at 2 wai, we excluded culture plates containing no symbiosisspecific runner hyphae and BAS (Bago et al. 1998), since these are immediately formed after attachment of hyphae to host roots. Such cultures were considered to be delayed in symbiosis development rather than affected by HIGS. SIS1-HIGS and EV control hairy roots were harvested at 4 wai for qRT-PCR analyses to determine the expression levels of SIS1, MtPT4, MtSbtM1, Protein ID 176092, RirG205060, and RiTEF.

\section{In silico efficiency and target prediction of SIS1-HIGS by NEXT-RNAi.}

The NEXT-RNAi software package (Horn et al. 2010) was downloaded and used to evaluate the RNAi efficiency and perform target prediction of the 330-bp partial sequence of SIS1 that was used for HIGS. The length of the siRNA was set at $21 \mathrm{nt}$. The efficiency was calculated using a 'weighted' method, and the minimal siRNA efficiency score was set at 63 , as explained by Shah et al. (2007). The minimal number of CA[ACGT] trinucleotide repeats was set at 6 . CDS datasets of $R$. irregularis and $M$. truncatula were obtained from the $R$. irregularis genome assembly (Gloin1, Joint Genome Institute) (Tisserant et al. 2013) and the Medicago Truncatula Genome Project v4.0 (Mt4.0v1; J. Craig Venter Institute) (Young et al. 2011).

\section{Microscopy.}

To assay the hyphal elongation and the spore germination rates, pictures including 10 to 32 spores were captured with the stereoscope SZX7 equipped with digital camera system DP21 (Olympus), and the spores in each picture were defined as one group. Hyphal elongation was measured using NIS-Elements AR software (Nikon), and the length per spore in each group was calculated for three biological replicates. The spore germination rate in each group was calculated using eight biological replicates.

For detailed observation of the arbuscules, the IRM was stained by Wheat Germ Agglutinin (WGA)-Alexa Fluor 594 conjugate (Life Technologies) as described by Takeda et al. (2015), and $\mathrm{z}$-stack images were obtained using a confocal microscope A1 (Nikon).

\section{ACKNOWLEDGMENTS}

We thank K. Akiyama for kindly providing strigolactone GR24. The confocal images were acquired at the Spectrography and Bioimaging Facility, National Institute for Basic Biology Core Research Facilities. The next generation sequencing was performed in cooperation with the Functional Genomics Facility, National Institute for Basic Biology Core Research Facilities. This work was supported by the Japan Society for the Promotion of Science KAKENHI, the Grant-in-Aid for Scientific Research on the Innovative Areas of 'Genome Science and Genetic Bases for the Evolution of Complex Adaptive Traits' (number 22128006) from the Ministry of Education, Culture, Sports, Science and Technology of Japan to M. Kawaguchi.

\section{LITERATURE CITED}

Akiyama, K., Matsuzaki, K., and Hayashi, H. 2005. Plant sesquiterpenes induce hyphal branching in arbuscular mycorrhizal fungi. Nature 435: 824-827.

Albert, M. 2013. Peptides as triggers of plant defence. J. Exp. Bot. 64: 5269-5279.

Aroca, R., Bago, A., Sutka, M., Paz, J. A., Cano, C., Amodeo, G., and Ruiz-Lozano, J. M. 2009. Expression analysis of the first arbuscular mycorrhizal fungi aquaporin described reveals concerted gene expression between salt-stressed and nonstressed mycelium. Mol. PlantMicrobe Interact 22:1169-1178.

Bago, B., Azcón-Aguilar, C., Goulet, A., and Piché, Y. 1998. Branched absorbing structures (BAS): A feature of the extraradical mycelium of symbiotic arbuscular mycorrhizal fungi. New Phytol. 139:375-388.

Bago, B., Pfeffer, P. E., and Shachar-Hill, Y. 2000. Carbon metabolism and transport in arbuscular mycorrhizas. Plant Physiol. 124:949-958.

Bécard, G., and Fortin, J. A. 1988. Early events of vesicular-arbuscular mycorrhiza formation on Ri T-DNA transformed roots. New Phytol. 108: 211-218.

Besserer, A., Bécard, G., Jauneau, A., Roux, C., and Séjalon-Delmas, N. 2008. GR24, a synthetic analog of strigolactones, stimulates the mitosis and growth of the arbuscular mycorrhizal fungus Gigaspora rosea by boosting its energy metabolism. Plant Physiol. 148:402-413.

Besserer, A., Puech-Pagès, V., Kiefer, P., Gomez-Roldan, V., Jauneau, A., Roy, S., Portais, J. C., Roux, C., Bécard, G., and Séjalon-Delmas, N. 2006. Strigolactones stimulate arbuscular mycorrhizal fungi by activating mitochondria. PLoS Biol. 4:e226.

Brundrett, M. C. 2009. Mycorrhizal associations and other means of nutrition of vascular plants: Understanding the global diversity of host plants by resolving conflicting information and developing reliable means of diagnosis. Plant Soil 320:37-77.

Danesh, Y. R., Mohammadi Goltapeh, E., Alizadeh, A., and Modarres Sanavy, M. 2006. Optimizing carrot hairy root production for monoxenic culture of arbuscular mycorrhizal fungi in Iran. J. Biol. Sci. (Faisalabad, Pak.) 6:87-91.

Doner, L. W., and Bécard, G. 1991. Solubilization of gellan gels by chelation of cations. Biotechnol. Tech. 5:25-28.

Feddermann, N., Muni, R. R., Zeier, T., Stuurman, J., Ercolin, F., Schorderet, M., and Reinhardt, D. 2010. The PAM1 gene of petunia, required for intracellular accommodation and morphogenesis of arbuscular mycorrhizal fungi, encodes a homologue of VAPYRIN. Plant J. 64:470481.

Felix, G., Duran, J. D., Volko, S., and Boller, T. 1999. Plants have a sensitive perception system for the most conserved domain of bacterial flagellin. Plant J. 18:265-276.

Furlan, V., Bartschi, H., and Fortin, J. A. 1980. Media for density gradient extraction of endomycorrhizal spores. T. Brit. Mycol. Soc. 75:336-338. 
Genre, A., Chabaud, M., Balzergue, C., Puech-Pagès, V., Novero, M., Rey, T., Fournier, J., Rochange, S., Bécard, G., Bonfante, P., and Barker, D. G. 2013. Short-chain chitin oligomers from arbuscular mycorrhizal fungi trigger nuclear $\mathrm{Ca}^{2+}$ spiking in Medicago truncatula roots and their production is enhanced by strigolactone. New Phytol. 198:190-202.

Genre, A., Chabaud, M., Timmers, T., Bonfante, P., and Barker, D. G. 2005. Arbuscular mycorrhizal fungi elicit a novel intracellular apparatus in Medicago truncatula root epidermal cells before infection. Plant Cell 17: 3489-3499.

Gómez-Gómez, L., and Boller, T. 2000. FLS2: An LRR receptor-like kinase involved in the perception of the bacterial elicitor flagellin in Arabidopsis. Mol. Cell 5:1003-1011.

Gomez-Roldan, V., Fermas, S., Brewer, P. B., Puech-Pagès, V., Dun, E. A., Pillot, J. P., Letisse, F., Matusova, R., Danoun, S., Portais, J. C., Bouwmeester, H., Bécard, G., Beveridge, C. A., Rameau, C., and Rochange, S. F. 2008. Strigolactone inhibition of shoot branching. Nature 455:189-194. Gutjahr, C., Radovanovic, D., Geoffroy, J., Zhang, Q., Siegler, H., Chiapello, M., Casieri, L., An, K., An, G., Guiderdoni, E., Kumar, C. S., Sundaresan, V., Harrison, M. J., and Paszkowski, U. 2012. The half-size ABC transporters STR1 and STR2 are indispensable for mycorrhizal arbuscule formation in rice. Plant J. 69:906-920.

Handa, Y., Nishide, H., Takeda, N., Suzuki, Y., Kawaguchi, M., and Saito, K. 2015. RNA-seq transcriptional profiling of an arbuscular mycorrhiza provides insights into regulated and coordinated gene expression in Lotus japonicus and Rhizophagus irregularis. Plant Cell Physiol. 56: 1490-1511.

Harrison, M. J., Dewbre, G. R., and Liu, J. 2002. A phosphate transporter from Medicago truncatula involved in the acquisition of phosphate released by arbuscular mycorrhizal fungi. Plant Cell 14:2413-2429.

Harrison, M. J., and van Buuren, M. L. 1995. A phosphate transporter from the mycorrhizal fungus Glomus versiforme. Nature 378:626-629.

Helber, N., Wippel, K., Sauer, N., Schaarschmidt, S., Hause, B., and Requena, N. 2011. A versatile monosaccharide transporter that operates in the arbuscular mycorrhizal fungus Glomus sp is crucial for the symbiotic relationship with plants. Plant Cell 23:3812-3823.

Horn, T., Sandmann, T., and Boutros, M. 2010. Design and evaluation of genome-wide libraries for RNA interference screens. Genome Biol. 11:R61.

Ivanov, S., Fedorova, E. E., Limpens, E., De Mita, S., Genre, A., Bonfante, P., and Bisseling, T. 2012. Rhizobium-legume symbiosis shares an exocytotic pathway required for arbuscule formation. Proc. Natl. Acad. Sci. U.S.A. 109:8316-8321.

Javot, H., Penmetsa, R. V., Terzaghi, N., Cook, D. R., and Harrison, M. J. 2007. A Medicago truncatula phosphate transporter indispensable for the arbuscular mycorrhizal symbiosis. Proc. Natl. Acad. Sci. U.S.A. 104: $1720-1725$.

Karimi, M., Inzé, D., and Depicker, A. 2002. GATEWAY vectors for Agrobacterium-mediated plant transformation. Trends Plant Sci. 7: 193-195.

Kloppholz, S., Kuhn, H., and Requena, N. 2011. A secreted fungal effector of Glomus intraradices promotes symbiotic biotrophy. Curr. Biol. 21: 1204-1209.

Kobae, Y., and Hata, S. 2010. Dynamics of periarbuscular membranes visualized with a fluorescent phosphate transporter in arbuscular mycorrhizal roots of rice. Plant Cell Physiol. 51:341-353.

Kobae, Y., Tamura, Y., Takai, S., Banba, M., and Hata, S. 2010. Localized expression of arbuscular mycorrhiza-inducible ammonium transporters in soybean. Plant Cell Physiol. 51:1411-1415.

Koltai, H., LekKala, S. P., Bhattacharya, C., Mayzlish-Gati, E., Resnick, N., Wininger, S., Dor, E., Yoneyama, K., Yoneyama, K., Hershenhorn, J., Joel, D. M., and Kapulnik, Y. 2010. A tomato strigolactone-impaired mutant displays aberrant shoot morphology and plant interactions. J. Exp. Bot. 61:1739-1749.

Kuhn, H., Küster, H., and Requena, N. 2010. Membrane steroid-binding protein 1 induced by a diffusible fungal signal is critical for mycorrhization in Medicago truncatula. New Phytol. 185:716-733.

Kunze, G., Zipfel, C., Robatzek, S., Niehaus, K., Boller, T., and Felix, G. 2004. The $\mathrm{N}$ terminus of bacterial elongation factor Tu elicits innate immunity in Arabidopsis plants. Plant Cell 16:3496-3507.

Lin, K., Limpens, E., Zhang, Z., Ivanov, S., Saunders, D. G., Mu, D., Pang, E., Cao, H., Cha, H., Lin, T., Zhou, Q., Shang, Y., Li, Y., Sharma, T., van Velzen, R., de Ruijter, N., Aanen, D. K., Win, J., Kamoun, S., Bisseling, T., Geurts, R., and Huang, S. 2014. Single nucleus genome sequencing reveals high similarity among nuclei of an endomycorrhizal fungus. PLoS Genet. 10:e1004078.

López-Pedrosa, A., González-Guerrero, M., Valderas, A., Azcón-Aguilar, C., and Ferrol, N. 2006. GintAMT1 encodes a functional high-affinity ammonium transporter that is expressed in the extraradical mycelium of Glomus intraradices. Fungal Genet. Biol. 43:102-110.
Ma, Y., Creanga, A., Lum, L., and Beachy, P. A. 2006. Prevalence of offtarget effects in Drosophila RNA interference screens. Nature 443: 359-363.

Maillet, F., Poinsot, V., André, O., Puech-Pagès, V., Haouy, A., Gueunier, M., Cromer, L., Giraudet, D., Formey, D., Niebel, A., Martinez, E. A., Driguez, H., Bécard, G., and Dénarié, J. 2011. Fungal lipochitooligosaccharide symbiotic signals in arbuscular mycorrhiza. Nature 469: 58-63.

Maldonado-Mendoza, I. E., Dewbre, G. R., and Harrison, M. J. 2001. A phosphate transporter gene from the extra-radical mycelium of an arbuscular mycorrhizal fungus Glomus intraradices is regulated in response to phosphate in the environment. Mol. Plant-Microbe Interact 14:1140-1148.

Mortazavi, A., Williams, B. A., McCue, K., Schaeffer, L., and Wold, B. 2008. Mapping and quantifying mammalian transcriptomes by RNA-Seq. Nat. Methods 5:621-628.

Nadal, M., and Paszkowski, U. 2013. Polyphony in the rhizosphere: Presymbiotic communication in arbuscular mycorrhizal symbiosis. Curr. Opin. Plant Biol. 16:473-479.

Nagalakshmi, U., Wang, Z., Waern, K., Shou, C., Raha, D., Gerstein, M., and Snyder, M. 2008. The transcriptional landscape of the yeast genome defined by RNA sequencing. Science 320:1344-1349.

Petersen, T. N., Brunak, S., von Heijne, G., and Nielsen, H. 2011. SignalP 4.0: Discriminating signal peptides from transmembrane regions. Nat. Methods 8:785-786.

Pumplin, N., and Harrison, M. J. 2009. Live-cell imaging reveals periarbuscular membrane domains and organelle location in Medicago truncatula roots during arbuscular mycorrhizal symbiosis. Plant Physiol. 151:809-819.

Pumplin, N., Mondo, S. J., Topp, S., Starker, C. G., Gantt, J. S., and Harrison, M. J. 2010. Medicago truncatula Vapyrin is a novel protein required for arbuscular mycorrhizal symbiosis. Plant J. 61:482-494.

Recorbet, G., Abdallah, C., Renaut, J., Wipf, D., and Dumas-Gaudot, E. 2013. Protein actors sustaining arbuscular mycorrhizal symbiosis: Underground artists break the silence. New Phytol. 199:26-40.

Redecker, D., Kodner, R., and Graham, L. E. 2000. Glomalean fungi from the Ordovician. Science 289:1920-1921.

Remy, W., Taylor, T. N., Hass, H., and Kerp, H. 1994. Four hundredmillion-year-old vesicular arbuscular mycorrhizae. Proc. Natl. Acad. Sci. U.S.A. 91:11841-11843.

Robinson, M. D., McCarthy, D. J., and Smyth, G. K. 2010. edgeR: A Bioconductor package for differential expression analysis of digital gene expression data. Bioinformatics 26:139-140.

Schroeder, A., Mueller, O., Stocker, S., Salowsky, R., Leiber, M., Gassmann, M., Lightfoot, S., Menzel, W., Granzow, M., and Ragg, T. 2006. The RIN: An RNA integrity number for assigning integrity values to RNA measurements. BMC Mol. Biol. 7:3.

Shah, J. K., Garner, H. R., White, M. A., Shames, D. S., and Minna, J. D. 2007. sIR: siRNA Information Resource, a web-based tool for siRNA sequence design and analysis and an open access siRNA database. BMC Bioinformatics 8:178.

Simon, L., Bousquet, J., Lévesque, C., and Lalone, M. 1993. Origin and diversification of endomycorrhizal fungi and coincidence with vascular land plants. Nature 363:67-69.

Stergiopoulos, I., and de Wit, P. J. 2009. Fungal effector proteins. Annu. Rev. Phytopathol. 47:233-263.

Sun, J., Nishiyama, T., Shimizu, K., and Kadota, K. 2013. TCC: An R package for comparing tag count data with robust normalization strategies. BMC Bioinformatics 14:219.

Takeda, N., Handa, Y., Tsuzuki, S., Kojima, M., Sakakibara, H., and Kawaguchi, M. 2015. Gibberellins interfere with symbiosis signaling and gene expression and alter colonization by arbuscular mycorrhizal fungi in Lotus japonicus. Plant Physiol. 167:545-557.

Takeda, N., Sato, S., Asamizu, E., Tabata, S., and Parniske, M. 2009. Apoplastic plant subtilases support arbuscular mycorrhiza development in Lotus japonicus. Plant J. 58:766-777.

Takeda, N., Tsuzuki, S., Suzaki, T., Parniske, M., and Kawaguchi, M. 2013. CERBERUS and NSP1 of Lotus japonicus are common symbiosis genes that modulate arbuscular mycorrhiza development. Plant Cell Physiol. 54:1711-1723.

Tian, C., Kasiborski, B., Koul, R., Lammers, P. J., Bücking, H., and Shachar-Hill, Y. 2010. Regulation of the nitrogen transfer pathway in the arbuscular mycorrhizal symbiosis: Gene characterization and the coordination of expression with nitrogen flux. Plant Physiol. 153: 1175-1187.

Tisserant, E., Malbreil, M., Kuo, A., Kohler, A., Symeonidi, A., Balestrini, R., Charron, P., Duensing, N., Frei dit Frey, N., Gianinazzi-Pearson, V., Gilbert, L. B., Handa, Y., Herr, J. R., Hijri, M., Koul, R., Kawaguchi, M., 
Krajinski, F., Lammers, P. J., Masclaux, F. G., Murat, C., Morin, E., Ndikumana, S., Pagni, M., Petitpierre, D., Requena, N., Rosikiewicz, P., Riley, R., Saito, K., San Clemente, H., Shapiro, H., van Tuinen, D., Bécard, G., Bonfante, P., Paszkowski, U., Shachar-Hill, Y. Y., Tuskan, G. A., Young, J. P., Sanders, I. R., Henrissat, B., Rensing, S. A., Grigoriev, I. V., Corradi, N., Roux, C., and Martin, F. 2013. Genome of an arbuscular mycorrhizal fungus provides insight into the oldest plant symbiosis. Proc. Natl. Acad. Sci. U.S.A. 110:20117-20122.

Tollot, M., Wong Sak Hoi, J., Van Tuinen, D., Arnould, C., Chatagnier, O., Dumas, B., Gianinazzi-Pearson, V., and Seddas, P. M. A. 2009. An STE12 gene identified in the mycorrhizal fungus Glomus intraradices restores infectivity of a hemibiotrophic plant pathogen. New Phytol. 181:693-707.

Trouvelot, A., Kough, J. L., and Gianinazzi-Pearson, V. 1986. Mesure du taux de mycorhization VA d'un système radiculaire. Recherche de méthodes d'estimation ayant une signification fonctionnelle. Pages 217-221 in: Physiological and Genetical Aspects of Mycorrhizae. INRA Press, Paris. van der Heijden, M. G. A., Martin, F. M., Selosse, M. A., and Sanders, I. R. 2015. Mycorrhizal ecology and evolution: The past, the present, and the future. New Phytol. 205:1406-1423.

Vogel, J. T., Walter, M. H., Giavalisco, P., Lytovchenko, A., Kohlen, W., Charnikhova, T., Simkin, A. J., Goulet, C., Strack, D., Bouwmeester, H. J., Fernie, A. R., and Klee, H. J. 2010. S1CCD7 controls strigolactone biosynthesis, shoot branching and mycorrhiza-induced apocarotenoid formation in tomato. Plant J. 61:300-311.

Wang, E., Schornack, S., Marsh, J. F., Gobbato, E., Schwessinger, B., Eastmond, P., Schultze, M., Kamoun, S., and Oldroyd, G. E. 2012. A common signaling process that promotes mycorrhizal and oomycete colonization of plants. Curr. Biol. 22:2242-2246.

Young, N. D., Debellé, F., Oldroyd, G. E. D., Geurts, R., Cannon, S. B., Udvardi, M. K., Benedito, V. A., Mayer, K. F. X., Gouzy, J., Schoof, H., Van de Peer, Y., Proost, S., Cook, D. R., Meyers, B. C., Spannagl, M., Cheung, F., De Mita, S., Krishnakumar, V., Gundlach, H., Zhou, S., Mudge, J., Bharti, A. K., Murray, J. D., Naoumkina, M. A., Rosen, B., Silverstein, K. A. T., Tang, H., Rombauts, S., Zhao, P. X., Zhou, P., Barbe, V., Bardou, P., Bechner, M., Bellec, A., Berger, A., Bergès, H.,
Bidwell, S., Bisseling, T., Choisne, N., Couloux, A., Denny, R., Deshpande, S., Dai, X., Doyle, J. J., Dudez, A. M., Farmer, A. D., Fouteau, S., Franken, C., Gibelin, C., Gish, J., Goldstein, S., González, A. J., Green, P. J., Hallab, A., Hartog, M., Hua, A., Humphray, S. J., Jeong, D. H., Jing, Y., Jöcker, A., Kenton, S. M., Kim, D. J., Klee, K., Lai, H., Lang, C., Lin, S., Macmil, S. L., Magdelenat, G., Matthews, L., McCorrison, J., Monaghan, E. L., Mun, J. H., Najar, F. Z., Nicholson, C., Noirot, C., O’Bleness, M., Paule, C. R., Poulain, J., Prion, F., Qin, B., Qu, C., Retzel, E. F., Riddle, C., Sallet, E., Samain, S., Samson, N., Sanders, I., Saurat, O., Scarpelli, C., Schiex, T., Segurens, B., Severin, A. J., Sherrier, D. J., Shi, R., Sims, S., Singer, S. R., Sinharoy, S., Sterck, L., Viollet, A., Wang, B. B., Wang, K., Wang, M., Wang, X., Warfsmann, J., Weissenbach, J., White, D. D., White, J. D., Wiley, G. B., Wincker, P., Xing, Y., Yang, L., Yao, Z., Ying, F., Zhai, J., Zhou, L., Zuber, A., Dénarié, J., Dixon, R. A., May, G. D., Schwartz, D. C., Rogers, J., Quétier, F., Town, C. D., and Roe, B. A. 2011. The Medicago genome provides insight into the evolution of rhizobial symbioses. Nature 480: 520-524.

Zhang, Q., Blaylock, L. A., and Harrison, M. J. 2010. Two Medicago truncatula half-ABC transporters are essential for arbuscule development in arbuscular mycorrhizal symbiosis. Plant Cell 22:1483-1497.

Zipfel, C., Kunze, G., Chinchilla, D., Caniard, A., Jones, J. D., Boller, T., and Felix, G. 2006. Perception of the bacterial PAMP EF-Tu by the receptor EFR restricts Agrobacterium-mediated transformation. Cell 125:749-760.

\section{AUTHOR-RECOMMENDED INTERNET RESOURCES}

Rhizophagus irregularis genome database of the Joint Genome Institute: http://genome.jgi.doe.gov/Gloin1/Gloin1.home.html

Estimation of the arbuscular mycorrhizal fungus colonization: http://www2.dijon.inra.fr/mychintec/Mycocalc-prg/download.html NEXT-RNAi website: http://b110-wiki.dkfz.de/confluence/display/nextrnai/NEXT-RNAi 